PYTHAGORAS: Jurnal Pendidikan Matematika

Volume 11 - Nomor 2, Desember 2016, (136-148)

Available online at: http://journal.uny.ac.id/index.php/pythagoras

\title{
Perbandingan Keefektifan Pendekatan Problem Solving dan Problem Posing dalam Pembelajaran Matematika pada Siswa SMP
}

\author{
Harinda Nurril Falach \\ SMK Bina Harapan, Jalan Kaliurang KM. 10 Gentan, Ngaglik, Sleman, Yogyakarta, Indonesia \\ Korespondensi Penulis. Email: inda1986@gmail.com
}

\begin{abstract}
Abstrak
Penelitian ini bertujuan untuk mendeskripsikan: (1) keefektifan pendekatan problem solving ditinjau dari kemampuan pemahaman dan penalaran matematis; (2) keefektifan pendekatan problem posing ditinjau dari kemampuan pemahaman dan penalaran matematis; dan (3) perbandingan keefektifan antara pendekatan pembelajaran problem solving dan problem posing ditinjau dari kemampuan pemahaman dan penalaran matematis siswa SMP pada pembelajaran bangun ruang sisi datar. Penelitian ini merupakan penelitian eksperimen semu (quasi experiment). Data dianalisis menggunakan one sample t-test, uji MANOVA menggunakan $T^{2}$ Hotteling, dan uji t kriteria Bonferroni. Hasil penelitian menunjukkan bahwa: (1) pendekatan problem solving efektif ditinjau dari kemampuan pemahaman dan penalaran matematis; (2) pendekatan problem posing efektif ditinjau dari kemampuan pemahaman dan penalaran matematis; dan (3) pendekatan problem solving lebih efektif dibandingkan problem posing ditinjau dari kemampuan pemahaman matematis tetapi pendekatan problem solving tidak lebih efektif dibandingkatn problem posing ditinjau dari kemampuan penalaran matematis siswa SMP pada pembelajaran bangun ruang sisi datar.
\end{abstract}

Kata Kunci: pendekatan problem solving, pendekatan problem posing, kemampuan pemahaman matematis, dan kemampuan penalaran matematis.

\section{The Effectiveness Comparison of Problem Solving and Problem Posing Approaches in Mathematics Learning Towards Junior High School Students}

\begin{abstract}
The aim of this study were to describe: (1) the effectiveness of problem solving approach viewed from mathematical understanding and reasoning ability; (2) the effectiveness of problem posing approach viewed from mathematical understanding and reasoning ability; and (3) the comparison of the effectiveness of polyhedral learning using problem solving and problem posing approach viewed from mathematical understanding and reasoning ability of Junior High School students. This study was a quasi experiment. The data were analyzed using one-sample $t$ test, MANOVA test with $T^{2}$ Hotteling's formula, and t-test with Bonferroni criterion. The results of the study show that: (1) the problem solving approach was effective viewed from mathematical understanding and reasoning ability; (2) the problem posing approach was effective viewed from mathematical understanding and reasoning ability; and (3) the problem solving approach was more effective than the problem posing approach viewed from mathematical understanding ability, but the problem solving approach was not more effective than the problem posing approach viewed from mathematical reasoning ability of Junior High School students in polyhedral learning.

Keywords: problem solving approach,problem posing approach, mathematical understanding ability, and mathematical reasoning ability

How to Cite: Falach, H. (2016). Perbandingan keefektifan pendekatan problem solving dan problem posing dalam pembelajaran matematika pada siswa SMP. PYTHAGORAS: Jurnal Pendidikan Matematika, 11(2). doi:http://dx.doi.org/10.21831/pg.v11i2.10635
\end{abstract}

Permalink/DOI: http://dx.doi.org/10.21831/pg.v11i2.10635 


\section{PENDAHULUAN}

Perkembangan ilmu pengetahuan dan teknologi informasi yang sangat pesat dewasa ini tidak terlepas dari perkembangan berbagai disiplin ilmu yang mendasarinya.Salah satu disiplin ilmu tersebut adalah matematika. Hal ini sesuai dengan pendapat Suherman, Turmudi, Suryadi, Herman, Suhendra, Prabawanto, Nurjanah, \& Rohayati (2003, p.25) yang menyatakan bahwa matematika adalah ratu dari ilmu pengetahuan. Maksudnya, matematika adalah sumber dari ilmu lain, yaitu perkembangan dan penemuan ilmu lain bergantung pada matematika. Selain itu, National Council of Teachers of Mathematics (2000, p.5) juga berpendapat bahwa di dalam dunia yang terus berubah, mereka yang memahami dan dapat mengerjakan matematika akan memiliki kesempatan dan pilihan yang banyak dalam menentukan masa depannya. Oleh karena itu, untuk menguasai dan menciptakan ilmu pengetahuan dan teknologi informasi serta mampu bertahan hidup pada keadaan yang selalu berubah dan kompetitif di masa depan diperlukan penguasaan matematika yang kuat sejak dini. Melihat begitu pentingnya matematika, maka pembelajaran matematika diberikan di semua jenjang pendidikan di Indonesia mulai dari sekolah dasar.

Keberhasilan pembelajaran matematika dapat dilihat dari prestasi belajar matematika. Hasil penelitian yang dilakukan oleh Trends in International Mathematics and Science Study (TIMSS) dan Program for International Assessment of Student (PISA) menunjukkan bahwa prestasi belajar matematika siswa SMP di Indonesia masih dalam kategori rendah. Berdasarkan penelitian yang dilakukan oleh PISA (OECD, 2010, pp.130-134) menunjukkan bahwa hampir tidak ada (mendekati 0\%) siswa di Indonesia yang berada pada kemampuan matematika level 6, bahkan hampir $80 \%$ siswa masih berada pada kemampuan matematika level 1 dari 6 level yang ditetapkan. Selain itu, rata-rata skor kemampuan matematika siswa Indonesia sebesar 371 masih dibawah rata-rata skor PISA 2009, yaitu 496. Sejalan dengan hasil penelitian PISA, hasil penelitian yang dilakukan oleh TIMSS (Mullis, Martin, Foy, Olson, Preuschoff, Erberber, Arora, dan Galia, 2008, p.48) menunjukkan bahwa pada tahun 1999, 2003 dan 2007, skor pencapaian prestasi belajar siswa berturut-turut 435, 411, dan 397. Skor ini masih di bawah skala rata-rata yang ditetapkan, yaitu 500. Adapun ranking yang diperoleh adalah sebagai berikut: tahun 1999 mendapat ranking 34 dari 38 negara, tahun 2004 mendapat ranking 35 dari 46 negara, tahun 2007 mendapat ranking 36 dari 48 negara, dan tahun 2009 mendapat ranking 61 dari 65 negara.Oleh karena itu, dapat disimpulkan bahwa prestasi belajar siswa matematika di Indonesia masih rendah.

Rendahnya prestasi belajar matematika juga dialami oleh siswa SMP Negeri 4 Ngaglik Sleman. Berdasarkan hasil ujian nasional tahun pelajaran 2006/2007 sampai 2010/2011, kemampuan siswa SMP Negeri 4 Ngaglik Sleman dalam mata pelajaran matematika lebih rendah jika dibandingkan dengan kemampuan mata pelajaran lain.

Geometri merupakan salah satu standar isi yang harus dipelajari oleh siswa dalam pembelajaran metematika (NCTM, 2000, p.29). Sejalan dengan pendapat tersebut, Barmby, Harries, Higgins dan Suggate (2007) menyatakan bahwa geometri adalah bagian dari matematika dengan kemampuan visual yang lebih mendominasi dibandingkan aljabar, yang mana didominasi oleh kemampuan berhitung. Akan tetapi, keduanya mempunyai peranan penting dalam masalah matematis real.Pada kenyataannya, prestasi belajar matematika siswa di bidang geometri belum dapat dikatakan memuaskan. Menurut hasil penelitian TIMSS tahun 2007 rata-rata prestasi belajar matematika kelas VIII di Indonesia untuk bidang geometri masih lebih rendah jika dibandingkan bidang lain maupun skala rata-rata yang ditetapkan oleh TIMSS.

Sejalan dengan penelitian TIMSS tahun 2007 di atas, hasil ujian nasional SMP Negeri 4 Ngaglik Sleman menunjukkan bahwa persentase daya serap siswa untuk beberapa soal mengenai geometri khususnya untuk soal bangun datar masih rendah. Berdasarkan fakta tersebut, perlu diadakan perbaikan pembelajaran matematika khususnya untuk materi pembelajaran bangun datar.

Dalam Kurikulum 2006 yaitu Kurikulum Tingkat Satuan Pendidikan (KTSP) disebutkan hal yang serupa, yaitu bahwa dengan belajar matematika diharapkan diperoleh kemampuan memahami konsep matematika, menjelaskan keterkaitan antar konsep dan mengaplikasikan konsep atau algoritma, secara luwes, akurat, efisien, dan tepat dalam pemahaman, menggunakan penalaran pada pola dan sifat, melakukan manipulasi matematika dalam membuat generalisasi, menyusun bukti, atau menjelaskan gagasan dan pernyataan matematika (Depdiknas, 2006). 
Menurut De Lange \& Romberg (2004) ada 8 kompetensi yang harus dipelajari dan dikuasai para siswa selama proses pembelajaran matematika di kelas, yaitu: (1) berpikir dan bernalar secara matematis; (2) berargumentasi secara matematis; (3) berpenalaran secara matematis; (4) memodelkan; (5) menyusun dan memecahkan masalah; (6) merepresentasi; (7) menyimbolkan; (8) menguasai alat dan teknologi. Hal ini juga diperkuat oleh National Council of Teachers of Matehematics atau NCTM (2000, p.7), yang menyatakan bahwa standar matematika sekolah meliputi standar isi dan standar proses. Standar proses meliputi pemahaman, penalaran dan pembuktian, keterkaitan, penalaran dan representasi. Kemudian dalam lampiran Permendiknas Nomor 23 Tahun 2006 tentang Standar Isi dijelaskan secara detail bahwa pelajaran matematika di sekolah menengah bertujuan untuk: memahami konsep matematika, menjelaskan keterkaitan antar konsep dan mengaplikasikan konsep atau algoritma secara luwes, akurat, efisien, dan tepat dalam pemahaman; menggunakan penalaran pada pola dan sifat, melakukan manipulasi matematika dalam membuat generalisasi, menyusun bukti, atau menjelaskan gagasan dan pernyataan matematika; memecahkan masalah yang meliputi kemampuan memahami masalah, merancang model matematika, menyelesaikan model dan menafsirkan solusi yang diperoleh; mengnalarankan gagasan dengan simbol, tabel, diagram, atau media lain untuk memperjelas keadaan atau masalah; dan memiliki sikap menghargai kegunaan matematika dalam kehidupan, yaitu memilik rasa ingin tahu, perhatian dan minat dalam mempelajari matematika, serta sikap ulet dan percaya diri dalam pemahaman.

Uraian tersebut menunjukkan pentingnya mempelajari matematika dalam menata kemampuan berpikir para siswa, bernalar, memecahkan masalah, berpenalaran, mengaitkan materi matematika dengan keadaan sesungguhnya, serta mampu menggunakan dan memanfaatkan teknologi.

Hasil observasi dan wawancara peneliti dengan guru dan siswa SMP Negeri 4 Ngaglik Sleman menunjukkan bahwa guru aktif memberikan penjelasan sedangkan siswa hanya mendengarkan, mencatat, menghafal rumus, dan mengerjakan latihan soal. Pembelajaran dengan pendekatan ini sangat tergantung oleh gaya pembelajaran guru, karena transfer ilmu lebih banyak berasal dari guru, bukan dari siswa atau interaksi antara guru dan siswa. Guru juga hanya memberikan masalah rutin kepada siswa. Akibatnya, dalam proses penyelesaian masalah, siswa mencontoh cara yang digunakan guru dalam menyelesaikan contoh soal. Oleh karena itu, siswa tidak menggunakan pengetahuan dan pengalaman yang dimiliki sebelumnya untuk menyelesaikan masalah, sehingga pengetahuan yang diperoleh siswa hanya bertahan sementara karena pengetahuan yang mereka peroleh bukan dengan mengkonstruk sendiri, melainkan hanya sekedar menghafal. Hal ini diperkuat oleh hasil wawancara peneliti dengan guru. Soal ulangan yang diberikan oleh guru biasanya soal yang berbentuk pilihan ganda, sehingga proses pemahaman dan penalaran tidak terlihat pada pekerjaan siswa. Selain itu, ketika guru memberikan tugas untuk diselesaikan, beberapa siswa terlihat hanya mencontoh pekerjaan teman. Keadaan ini mengakibatkan kemampuan pemahaman dan penalaran matematis siswa tidak berkembang dengan baik.

Pemahaman sebagai terjemahan dari istilah understanding diartikan sebagai penyerapan arti suatu materi bahan yang dipelajari. Untuk memahami suatu objek secara mendalam seseorang harus mengetahui: (1) objek itu sendiri; (2) relasinyadengan objek lain yang sejenis; (3) relasinya dengan objek lain yang tidak sejenis; (4) relasi-dual dengan objek lainnya yang sejenis; dan (5) relasi dengan objek dalam teori lainnya (Michener, 1978). Menurut Driver \& Leach (1993) pemahaman adalah kemampuan untuk menjelaskan suatu situasi atau suatu tindakan. Dari pengertian ini ada tiga aspek dalam pemahaman, yaitu kemampuan mengenal, kemampuan menjelaskan, dan menarik kesimpulan. Menurut Haylock \& Cockbum (2008, pp.7-8) belajar berdasarkan pemahaman dapat bertahan lebih kekal, lebih memuaskan secara psikologis dan lebih bermakna dalam praktek pembelajaran. Mengembangkan pemahaman dalam pembelajaran matematika, bagi guru tantangannya adalah untuk mengidentifikasi cara berfikir matematis yang paling signifikan terhadap suatu subyek.

Istilah penalaran berasal dari kata reasoning yang berarti jalan pikiran. Shurter \& Pierce (Dahlan, 2004, p.21) menyatakan bahwa penalaran (reasoning) merupakan proses pencapaian kesimpulan logis berdasarkan fakta dan sumber yang relevan, pentransformasian yang diberikan dalam urutan tertentu untuk menjangkau kesimpulan. Menurut Keraf (1982, p.2) penalaran diartikan sebagai proses berpikir yang berusaha menghubung-hubungkan fakta fakta 
atau evidensi-evidensi yang diketahui menuju kepada suatu kesimpulan. Penalaran matematis terjadi melalui pembuatan dugaan, penyelidikan dan merepresentasikan hasil kemudian menjelaskan dan memberikan kesimpulan. Menurut Martin \& Kashmer (2009) penalaran dapat dianggap sebagai proses menarik kesimpulan atas dasar bukti atau menyatakan asumsi. NCTM (2000) mendefinisikan kebiasaan penalaran sebagai "cara yang produktif pemikiran yang menjadi umum dalam proses penyelidikan matematika dan pengambilan akal." Lithner (2012) mendefinisikan penalaran sebagai garis pemikiran yang digunakan untuk menghasilkan pernyataan dan kesimpulan ketika memecahkan masalah. Penalaran tidak harus didasarkan pada logika formal dan karena itu tidak terbatas pada bukti, selama ada alasan yang masuk akal dan mendukungnya. Hal ini menggambarkan bahwa penalaran digunakan dalam arti luas untuk menunjukkan kualitas suatu argumentasi. Penalaran dapat dilihat sebagai proses berfikir, sebagai produk dari proses berfikir, atau karena keduanya. Menurut English $(2009$, p.27) proses umum dari penalaran matematis yaitu menyusun dan menguji konjektur (conjecturing), menemukan pola atau sifat dari gejala matematik untuk membuat generalisasi (generalizing), dan menyusun pembuktian langsung, tak langsung, dan menggunakan induksi matematik (investigating why).

Untuk mendorong siswa agar mampu mengembangkankan kemampuan pemahaman dan penalaran matematis dengan baik, perlu diterapkan pendekatan pembelajaran yang mendukung. Pendekatan pembelajaran yang dikembangkan harus memberikan kesempatan yang luas kepada siswa untuk menggali segala kemampuan dan pengalaman yang dimiliki. Jika pendekatan pembelajaran yang digunakan hanya terfokus pada guru, siswa tidak mempunyai kesempatan untuk melakukan pemahaman dan penalaran matematis.

Suatu pembelajaran matematika akan berjalan dengan efektif apabila seorang guru menggunakan berbagai macam metode dan pendekatan yang juga terdiri atas media dan sumber pembelajaran. Pendekatan pembelajaran dapat diartikan sebagai titik tolak atau sudut pandang kita terhadap proses pembelajaran, yang merujuk pada pandangan tentang terjadinya suatu proses yang sifatnya masih sangat umum, di dalamnya mewadahi, menginspirasi, menguatkan, dan melatari metode pembelajaran dengan cakupan teoretis tertentu. Terdapat beberapa pendekatan dalam pembelajaran, diantaranya adalah pendekatan problem solving dan problem posing. Menurut Shanti \& Abadi (2015, p.133) pendekatan pembelajaran problem solving dan problem posing efektif dalam pembelajaran matematika.Menurut Xia, Lu \& Wang (2008, p.153) matematika terdiri atas dua aspek yaitu problem posing dan problem solving.

Pendekatan problem solving merupakan salah satu bagian dari kurikulum matematika yang penting. Problem solving sebagai pendekatan pembelajaran diperkenalkan oleh John Dewey (Orlich, Harder, Callahan, Trevisan, Brown, dan Miller, 2012, p.309). John Dewey mengembangkan pendekatan problem solving menyerupai metode inquiry, perencanaan yang cermat (careful planning) dan skill building yang sistematik. Sehingga pendekatan problem solving fokus pada concept of experience. Haylock \& Thangata (2007, pp.145-146) menyatakan bahwa pemecahan masalah adalah situasi dimana siswa menggunakan pengetahuan dan penalaran matematika untuk menyelesaikan permasalahan. Hal ini menunjukkan bahwa pemecahan masalah juga penting untuk meningkatkan kemampuan penalaran matematika karena dalam memecahkan masalah matematika siswa sangat memerlukan pengetahuan dan kemampuan penalaran matematika sehingga dapat menyelesaikan permasalahan tersebut. Pembelajaran matematika menggunakan pendekatan problem solving menjadi penting karena matematika merupakan pengetahuan yang logis, sistematis, berpola, artifisial, abstrak, dan yang tak kalah penting menghendaki justifikasi atau pembuktian. Sejalan dengan pendapat O'Shea (2010, p.1) menyatakan "The pre-requisites to success in problem solving may lie in grasping the basic computational skills but mathematical problem solving must be seen as one of the ultimate goals of mathematics teaching. The revised curriculum suggests that the child will construct new mathematical knowledge through continued exploration utilising mathematical problem solving. " Artinya adalah prasyarat untuk sukses dalam memecahkan masalah mungkin terletak dalam menangkap keterampilan komputasi dasar tetapi pemecahan masalah matematika harus dilihat sebagai salah satu tujuan utama pembelajaran matematika. Kurikulum direvisi menunjukkan bahwa anak akan mengkonstruksi pengetahuan baru melalui eksplorasi lanjutan yang memanfaatkan pemecahan masalah matematika. 
Menurut Melianingsih \& Sugiman (2015, p.214) pendekatan problem solving mampu mendorong siswa membuat hubungan antara pengetahuan yang dimilikinya dengan penerapannya dalam kehidupan mereka sebagai anggota keluarga dan masyarakat. Dalam pembelajaran tersebut guru akan berperan sebagai pengaruh dan pembimbing untuk membantu siswa mencapai tujuan pembelajaran. Sesuatu yang baru akan diperoleh dari pengalaman masing-masing siswa bukan dari apa kata guru. Selanjutnya siswa akan menentukan solusi dari masalah matematika yang mereka temukan. Dengan konsep pembelajaran tersebut, hasil pembelajaran diharapkan akan lebih bermakna bagi siswa. Proses pembelajaran berlangsung alamiah dalam bentuk siswa bekerja dan mengalami, menemukan masalah dan membuat solusinya, sehingga proses pembelajaran tidak lagi sebagai proses mentransfer pengetahuan dari guru ke siswa.

Problem posing merupakan komponen penting dari suatu pembelajaran matematika dan dianggap sebagai bagian yang penting dari suatu penyelesaian matematis (Brown, Walter \& NCTM dalam Lavy \& Shriki, 2007, p.1). Problem posing menghasilkan suatu masalah dan pertanyaan baru yang ditujukan untuk mengeksplorasi suatu situasi tertentu serta memformulasikan kembali masalah baru selama proses pemecahan itu berlangsung (Silver, 1996, p.2-3). Menurut Nugraha \& Mahmudi (2015, p.119) pembelajaran dengan problem posing lebih unggul dibandingkan pembelajaran konvensional. Dengan menggunakan pendekatan problem posing, siswa diharapkan membuat atau mengajukan pertanyaan sendiri sesuai dengan permasalahan yang dihadapi sehari-hari yang berkaitan dengan materi yang sedang dipelajari untuk diselesaikan sendiri oleh siswa tanpa harus dijawab langsung oleh guru.

Penelitian ini diharapkan akan mampu memberikan sumbangan dalam pembelajaran matematika, terutama yang berkaitan dengan bagaimana keefektifan pendekatan problem solving dan problem posing ditinjau dari kemampuan pemahaman dan penalaran matematis siswa di SMP Negeri 4 Ngaglik pada materi bangun ruang sisi datar.

\section{METODE}

Jenis penelitian ini adalah eksperimen semu (quasi experimental). Desain yang digunakan pada penelitian ini adalah desain yang memberikan pre-test sebelum perlakuan dan post-test sesudah perlakuan. Penelitian ini dilaksanakan di SMP Negeri 4 Ngaglik Sleman. Penelitian dilaksanakan pada semester genap tahun pelajaran 2012/2013 tepatnya pada bulan Februari hingga April 2013. Adapun populasi dalam penelitian ini adalah seluruh siswa kelas VIII SMP Negeri 4 Ngaglik Sleman tahun pelajaran 2012/2013 yang terdiri atas 4 kelas.Pengambilan sampel dalam penelitian ini dengan mengambil secara acak 2 dari 4 kelas yang ada. Berdasarkan pengambilan sampel yang telah dilakukan diperoleh kelas VIIIB sebagai kelas dengan pendekatan problem solving dan kelas VIIIC sebagai kelas dengan pendekatan problem posing.

Variabel bebas dalam penelitian ini adalah pendekatan pembelajaran (problem solving dan problem posing) dan variabel terikatnya adalah kemampuan pemahaman dan penalaran matematis. Instrumen penelitian yang digunakan adalah tes kemampuan pemahaman dan penalaran matematis yang terdiri atas 8 soal uraian yang terdiri dari 4 soal uraian untuk mengukur kemampuan pemahaman, dan 4 soal untuk mengukur kemampuan penalaran.

Langkah-langkah pengumpulan data yang digunakan peneliti adalah sebagai berikut: menyusun instrumen yang akan digunakan dalam penelitian, seperti kisi-kisi soal pretest dan posttest, soal pre-test dan posttest, rubrik penskoran sesuai dengan variabel yang akan diteliti, serta soal-soal latihan, dan pekerjaan rumah; menyusun perangkat pembelajaran, meliputi silabus, Rencana Pelaksanaan Pembelajaran (RPP), dan Lembar Kegiatan Siswa (LKS); menentukan validitas isi instrumen dengan expert judgment atau meminta tiga orang dosen untuk memvalidasi instrumen yang telah dibuat; melakukan revisi instrumen sesuai dengan saran validator; melakukan uji coba instrumen penelitian; menentukan validitas konstruk dan mengestimasi nilai reliabilitas berdasarkan data hasil uji coba instrument; melakukan revisi instrumen berdasarkan hasil validitas konstruk; memberikan pre-test pada kedua kelas sebelum diberikan perlakuan; memberikan perlakuan sesuai hasil pengambilan sampel; dan memberikan post-test pada kedua kelas setelah diberikan perlakuan.

Teknik analisis data pada penelitian ini dilakukan dengan analisis deskriptif, uji asumsi analisis, dan pengujian hipotesis. Analisis deskriptif digunakan untuk mendiskripsikan data. Data yang dideskripsikan adalah hasil pre-test dan posttest kelas dengan pembelajaran problem solving dan problem posing. Untuk mendiskripsikan data digunakan teknik statistik yang meliputi rata-rata, ragam (varians), dan sim- 
pangan baku. Data yang telah terkumpul tersebut akan dianalisis menggunakan uji statistik inferensia. Sebelum dilakukan uji statistik inferensia, terlebih dahulu dilakukan pengujian asumsi analisis yang terdiri dari uji normalitas dan uji homogenitas (Stevens, 2002, p.257). Uji normalitas dilakukan secara manual dengan rumus jarak mahalanobis. Uji ini dilakukan pada data hasil pretest dan posttest kemampuan pemahaman dan penalaran matematis.Statistik uji yang digunakan adalah rumus jarak Mahalanobis. Data dikatakan berasal dari populasi yang berdistribusi normal multivariat jika sekitar $50 \%$ data memiliki nilai $d_{j}^{2} \leq \chi_{(2 ; 0,5)}^{2}$. (Johnson \& Wichern, 2007, p.186-187). Dengan $d_{j}^{2}$ adalah jarak Mahalanobis setiap pengamatan dengan $j=1,2, \ldots, n$.

Uji homogenitas dilakukan untuk mengetahui kesamaan matriks varians-kovarians skor kemampuan pemahaman dan penalaran matematis secara simultan atau secara multivariat dengan uji Box's $M$ dan kesamaan variansi masing-masing variabel terikat (univariat) dengan uji Levene's. Kemudian dilanjutkan dengan pengujian hipotesis yang diawali dengan uji univariat menggunakan one sample t-test. Pengujian ini dilakukan untuk menganalisis apakah pendekatan pembelajaran problem solving dan problem posing efektif terhadap kemampuan pemahaman dan penalaran matematis. Setelah pengujian menggunakan one sample $t$ test, pengujian hipotesis dilanjutkan dengan uji beda rata-rata multivariat menggunakan uji $\mathrm{F}$ dengan rumus $T^{2}$ Hotteling. Ketiga pengujian ini dilakukan dengan bantuan software SPSS 22.0 for windows. Keputusan diambil pada taraf sigifikansi $5 \%$.

\section{HASIL DAN PEMBAHASAN}

Data dalam penelitian ini terdiri dari hasil skor pretest dan posttest kemampuan pemahaman dan penalaran matematis dari kelas pembelajaran problem solving dan problem posing. Skor pre-test digunakan untuk mengetahui kemampuan awal pemahaman dan penalaran matematis siswa, sedang skor post-test untuk mengetahui kemampuan akhir pemahaman dan penalaran matematis siswa.Secara ringkas, skor hasil pretest dan posttest pemahaman matematis untuk kedua kelas disajikan pada Tabel 1 dan Tabel 2.
Tabel 1. Persentase Skor Tiap Aspek pada

Kemampuan Pemahaman Matematis

\begin{tabular}{ccccc}
\hline & \multicolumn{2}{c}{ Problem solving } & \multicolumn{2}{c}{ Problem posing } \\
\cline { 2 - 5 } Pretest & Posttest & Pretest & Posttest \\
\hline PMH 1 & $58,82 \%$ & $100 \%$ & $61,76 \%$ & $100 \%$ \\
PMH 2 & $61,76 \%$ & $100 \%$ & $62,75 \%$ & $100 \%$ \\
PMH 3 & $48,04 \%$ & $100 \%$ & $43,14 \%$ & $100 \%$ \\
PMH 4 & $0 \%$ & $88,24 \%$ & $0 \%$ & $89,22 \%$ \\
PMH 5 & $18,14 \%$ & $96,57 \%$ & $14,71 \%$ & $66,67 \%$ \\
PMH 6 & $0 \%$ & $39,22 \%$ & $0,65 \%$ & $44,12 \%$ \\
PMH 7 & $0 \%$ & $36,27 \%$ & $0 \%$ & $32,35 \%$ \\
\hline
\end{tabular}

Keterangan:

PMH 1: menyatakan ulang sebuah konsep

PMH 2: mengklasifikasi objek menurut sifat-sifat tertentu sesuai dengan konsepnya

PMH 3: memberi contoh dan bukan contoh dari konsep

PMH 4: menyajikan konsep dalam berbagai bentuk reprentasi matematika

PMH 5: mengembangkan syarat perlu atau syarat cukup darisuatu konsep

PMH 6: menggunakan, memanfaatkan dan memilih prosedur atau operasi tertentu.

PMH 7: mengaplikasikan konsep atau algoritma ke pemecahanmasalah

Untuk lebih jelasnya persentase tiap aspek kemampuan pemahaman matematis siswa, baik kelas dengan pendekatan problem solving maupun kelas dengan pendekatan problem posing dapat dilihat dalam diagram seperti Gambar 1.

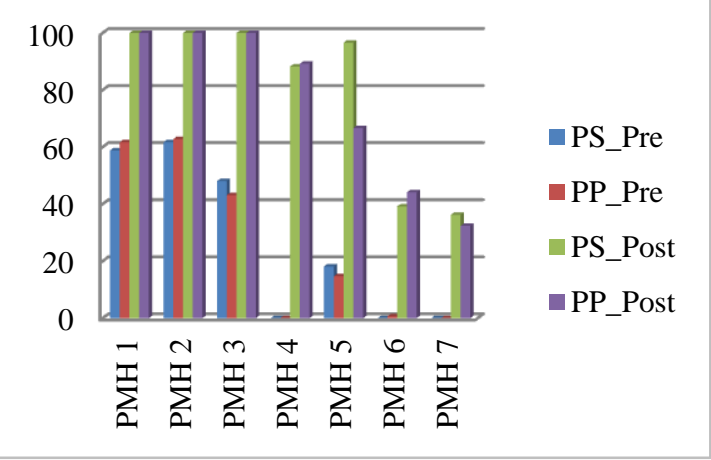

Gambar 1.Diagram Persentase Skor Tiap Aspek pada Kemampuan Pemahaman Matematis

Keterangan :

PS_Pre: Hasil persentase skor pretest tiap aspek kemampuan pemahaman matematis pada kelas dengan pendekatan problem solving

PP_Pre: Hasil persentase skor pretest tiap aspek kemampuan pemahaman matematis pada kelas dengan pendekatan problem posing

PS_Post: Hasil persentase skor posttest tiap aspek kemampuan pemahaman matematis pada kelas dengan pendekatan problem solving

PP_Post: Hasil persentase skor post-test tiap aspek kemampuan pemahaman matematis pada kelas dengan pendekatan problem posing 
Tabel 2. Rata-rata, Standar Deviasi, Skor Tertinggi dan Skor Terendah Tes Kemampuan Pemahaman Matematis

\begin{tabular}{lcccc}
\hline \multirow{2}{*}{ Deskripsi } & \multicolumn{2}{c}{ Problem solving } & \multicolumn{2}{c}{ Problem posing } \\
\cline { 2 - 5 } & Pretest & Posttest & Pretest & Posttest \\
\hline Rata-rata & 20,79 & 80,88 & 20,53 & 73,84 \\
Stand. Dev & 4,17 & 11,64 & 6,01 & 11,37 \\
Skor & 28,57 & 94,74 & 38,46 & 94,74 \\
tertinggi & & & & \\
$\begin{array}{l}\text { Skor } \\
\text { terendah }\end{array}$ & 10,71 & 50 & 10.71 & 50 \\
\hline
\end{tabular}

Untuk lebih jelasnya rata-rata skor kemampuan pemahaman matematis siswa, baik kelas dengan pendekatan problem solving maupun kelas dengan pendekatan problem posing dapat dilihat dalam Gambar 2.

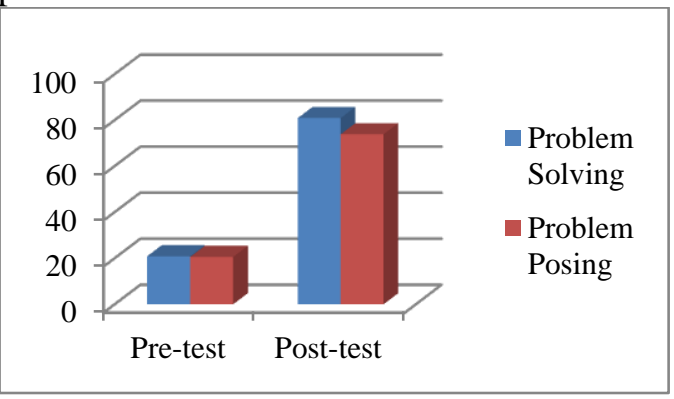

Gambar 2.Diagram Rata-rata Skor Kemampuan Pemahaman Matematis

Dari Tabel 1 dapat diketahui bahwa secara umum persentase skor tiap aspek pada kemampuan pemahaman matematis baik pada kelas dengan pendekatan problem solving maupun kelas dengan pendekatan problem posing hampir sama. Terdapat peningkatan persentase skor tiap aspek pada hasil pre-test dan post-test. Siswa dapat dikatakan menguasai aspek untuk menyatakan ulang sebuah konsep, mengklasifikasi objek menurut sifat-sifat tertentu sesuai dengan konsepnya, dan memberi contoh dan bukan contoh dari konsep dengan baik berdasarkan hasil post-test yang menunjukkan persentase mencapai $100 \%$ baik kelas dengan pendekatan problem solving maupun kelas dengan pendekatan problem posing. Selisih persentase skor tiap aspek yang terlihat cukup besar adalah pada hasil post-test aspek mengembangkan syarat perlu atau syarat cukup dari suatu konsep yaitu sebesar $29,9 \%$.

Dari Tabel 2 dapat diketahui bahwa selisih rata-rata hasil pretest kemampuan pemahaman matematis siswa dengan pendekatan problem solving dan problem posing adalah 0,2747. Selisih rata-rata hasil post-test kemampuan pemahaman pada siswa dengan pendekatan problem solving dan problem posing adalah
7,0436. Namun jika diperhatikan dari standar deviasi kedua kelompok baik pada siswa dengan pendekatan problem solving dan problem posing relatif sama. Untuk mengetahui apakah secara umum selisih rata-rata dan standar deviasi di sekolah itu sama atau berbeda, maka diperlukan pengujian lebih lanjut.

Data secara ringkas, skor hasil pretest dan posttest kemampuan penalaran matematis untuk kedua kelompok perlakuan disajikan pada Tabel 3 dan Tabel 4.

Tabel 3. Persentase Skor Tiap Aspek pada Kemampuan Penalaran Matematis

\begin{tabular}{lcccc}
\hline & \multicolumn{2}{c}{ Problem solving } & \multicolumn{2}{c}{ Problem posing } \\
\cline { 2 - 5 } & Pre-test & Post-test & Pre-test & Post-test \\
\hline PNL 1 & $66,67 \%$ & $100 \%$ & $66,67 \%$ & $100 \%$ \\
PNL 2 & $66,67 \%$ & $99,02 \%$ & $66,67 \%$ & $100 \%$ \\
PNL 3 & $66,67 \%$ & $87,25 \%$ & $65,69 \%$ & $93,14 \%$ \\
PNL 4 & $60,78 \%$ & $95,10 \%$ & $55,88 \%$ & $89,22 \%$ \\
PNL 5 & $34,80 \%$ & $77,45 \%$ & $26,96 \%$ & $80,39 \%$ \\
PNL 6 & $7,84 \%$ & $60,78 \%$ & $0 \%$ & $74,51 \%$ \\
PNL 7 & $0,98 \%$ & $44,12 \%$ & $0 \%$ & $52,45 \%$ \\
\hline
\end{tabular}

Keterangan:

PNL 1: menyajikan pernyataan matematika secara lisan, tertulis, gambar dan diagram

PNL 2: mengajukan dugaan

PNL 3: melakukan manipulasi matematik

PNL 4: menarik kesimpulan, menyusun bukti, memberikan alasan atau bukti terhadap kebenaran solusi

PNL 5: menarik kesimpulan dari pernyataan

PNL 6: memeriksa kesahihan suatu argumen

PNL 7: menemukan pola atau sifat dari gejala matematik untuk membuat generalisasi.

Untuk lebih jelasnya persentase tiap aspek kemampuan penalaran matematis siswa, baik kelas dengan pendekatan problem solving maupun kelas dengan pendekatan problem posing dapat dilihat dalam diagram seperti Gambar 3.

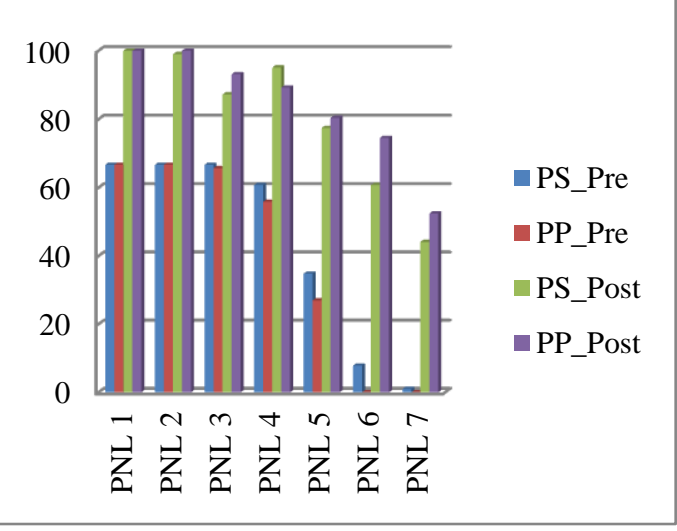

Gambar 3.Diagram Persentase Skor Tiap Aspek pada Kemampuan Penalaran Matematis 
Keterangan

PS_Pre : Hasil persentase skor pre-test tiap aspek kemampuan penalaran matematis pada kelas dengan pendekatan problem solving

PP_Pre : Hasil persentase skor pre-test tiap aspek kemampuan penalaran matematis pada kelas dengan pendekatan problem posing

PS_Post : Hasil persentase skor post-test tiap aspek kemampuan penalaran matematis pada kelas dengan pendekatan problem solving

PP_Post : Hasil persentase skor post-test tiap aspek kemampuan penalaran matematis pada kelas dengan pendekatan problem posing

Tabel 4. Rata-rata, Standar Deviasi, Skor Tertinggi dan Skor Terendah Tes Kemampuan Penalaran Matematis

\begin{tabular}{|c|c|c|c|c|}
\hline \multirow{2}{*}{ Deskripsi } & \multicolumn{2}{|c|}{ Problem solving } & \multicolumn{2}{|c|}{ Problem posing } \\
\hline & Pretest & Posttest & Pretest & Posttest \\
\hline Rata-rata & 40,81 & 78,73 & 37,43 & 82,92 \\
\hline $\begin{array}{l}\text { Standar } \\
\text { deviasi }\end{array}$ & 7,04 & 11,99 & 5,83 & 13,99 \\
\hline Varians & 49,53 & 143,68 & 33,89 & 195,63 \\
\hline $\begin{array}{l}\text { Skor } \\
\text { tertinggi }\end{array}$ & 60 & 100 & 47,27 & 100 \\
\hline $\begin{array}{l}\text { Skor } \\
\text { terendah }\end{array}$ & 27,27 & 53,85 & 25,45 & 50 \\
\hline
\end{tabular}

Untuk lebih jelasnya rata-rata skor kemampuan pemahaman matematis siswa, baik kelas dengan pendekatan problem solving maupun kelas dengan pendekatan problem posing dapat dilihat pada Gambar 4.

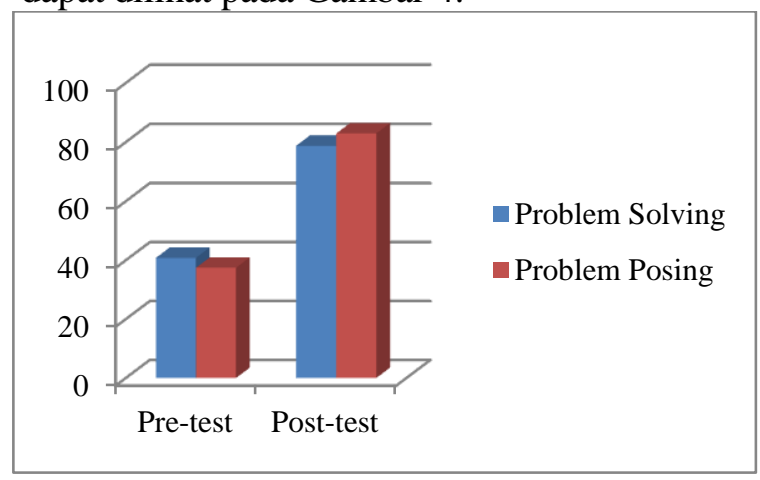

Gambar 4.Diagram Rata-rata Skor Kemampuan Pemahaman Matematis

Dari Tabel 3 dapat diketahui bahwa secara umum persentase skor tiap aspek pada ke- mampuan penalaran matematis baik pada kelas dengan pendekatan problem solving maupun kelas dengan pendekatan problem posing hampir sama. Terdapat peningkatan persentase skor tiap aspek pada hasil pre-test dan post-test. Siswa dapat dikatakan menguasaiaspek menyajikan pernyataan matematika secara lisan, tertulis, gambar dan diagram, mengajukan dugaan, melakukan manipulasi matematik, menarik kesimpulan, menyusun bukti, memberikan alasan atau bukti terhadap kebenaran solusi, dan menarik kesimpulan dari pernyataan dengan baik berdasarkan hasil persentase skor tes diatas $75 \%$.

Dari Tabel 4 dapat diketahui bahwa selisih rata-rata hasil pre-testkemampuan penalaran matematis siswa dengan pendekatan problem solving dan problem posing adalah 3,3694. Selisih rata-rata hasil post-test kemampuan penalaran pada siswa dengan pendekatan prob-lem solving dan problem posing adalah 4,1853. Namun jika diperhatikan dari standar deviasi kedua kelompok baik pada siswa dengan pen-dekatan problem solving dan problem posing relatif sama. Untuk mengetahui apakah secara umum selisih rata-rata dan standar deviasi di sekolah itu sama atau berbeda, maka diperlukan pengujian lebih lanjut.

Sebelum dilakukan pengujian hipotesis, asumsi yang harus dipenuhi adalah asumsi normalitas dan homogenitas data.Uji normalitas dilakukan untuk mengetahui apakah sampel yang diambil dari masing-masing varibel terikat berasal dari populasi yang berdistribusi normal atau tidak. Uji normalitas dilakukan secara manual dengan rumus jarak mahalanobis. Ringkasan hasil analisis uji normalitas disajikan dalam Tabel 5. Uji homogenitas dilakukan untuk mengetahui kesamaan matriks varians-kovarians skor kemampuan pemahaman dan penalaran matematis secara simultan atau secara multivariat dengan uji Box's $M$ dan kesamaan varians masing-masing variabel terikat (univariat) dengan uji Levene's. Ringkasan hasil analisis uji homogenitas multivariat disajikan Tabel 6.

Tabel 5. Ringkasan Hasil Analisis Uji Normalitas Multivariat

\begin{tabular}{llcccc}
\hline \multirow{2}{*}{ Kelas } & \multicolumn{1}{c}{$\mathbf{V}$} & $\boldsymbol{\chi}_{\text {tabel }}^{2}$ & $\begin{array}{c}\text { Jumlah } \\
\text { siswa }\end{array}$ & $\begin{array}{c}\text { Jumlah Siswa dengan nilai } \\
\boldsymbol{d}_{\boldsymbol{j}}^{2} \leq \boldsymbol{\chi}_{(\mathbf{2} ; \mathbf{0}, \mathbf{5})}^{2}\end{array}$ & $\begin{array}{c}\text { \% Jumlah Siswa dengan nilai } \\
\boldsymbol{d}_{\boldsymbol{j}}^{2} \leq \boldsymbol{\chi}_{(\mathbf{2} ; \mathbf{0}, \mathbf{5})}^{2}\end{array}$ \\
\hline PS & Pretest & 1,386 & 34 & 20 & $58,82 \%$ \\
& Posttest & 1,386 & 34 & 18 & $52,94 \%$ \\
PP & Pretest & 1,386 & 34 & 19 & $55,88 \%$ \\
& Posttest & 1,386 & 34 & 17 & $50 \%$ \\
\hline
\end{tabular}




\section{Pythagoras, 11 (2), Desember 2016 - 144}

Harinda Nurril Falach

Keterangan:

Kls: Kelas yang diuji

V: Variabel yang diuji

PS: Pendekatan Problem Solving

PP: Pendekatan Problem Posing

Suatu sampel dikatakan berasal dari populasi yang berdistribusi normal $\left(\mathrm{H}_{0}\right.$ diterima $)$ jika sekitar $50 \%$ banyak data memiliki nilai $d_{j}^{2} \leq \chi_{(2 ; 0,5)}^{2}$. Dari Tabel 5 diperoleh simpulan bahwa untuk pretest dan posttest baik kelas dengan pendekatan problem solving maupun kelas dengan pendekatan problem posing memiliki sampel berasal dari populasi yang berdistribusi normal.

Tabel 6. Ringkasan Hasil Analisis Uji

Homogenitas Matriks Varians-Kovarians

\begin{tabular}{lccc}
\hline Variabel & Box's M & F & Sig \\
\hline Awal & 6,362 & 2,051 & 0,104 \\
Akhir & 1,978 & 0,638 & 0,591 \\
\hline
\end{tabular}

Suatu kelas sampel dikatakan tidak homogen $\left(\mathrm{H}_{0}\right.$ ditolak) jika nilai signifikansinya kurang dari atau sama dengan taraf signifikansi yang telah ditentukan, yaitu 5\% atau 0,05. Dari Tabel 6 diperoleh simpulan bahwa baik pada kemampuan awal maupun kemampuan akhir matriks varians-kovarians variabel-variabel terikatnya untuk kelas dengan pendekatan problem solving maupun kelas dengan pendekatan problem posing homogen.

Selain uji homogenitas multivariat, dianalisis juga homogenitas variansi variabel terikat secara univariat.Berikut ringkasan hasil analisis uji homogenitas univariat yang disajikan dalam Tabel 7.

Tabel 7. Ringkasan Hasil Analisis Uji Homogenitas Varians

\begin{tabular}{cccccc}
\hline \multicolumn{2}{c}{ Variabel Terikat } & F & df1 & df2 & Sig \\
\hline \multirow{2}{*}{ Awal } & PMH & 2,196 & 1 & 66 & 0,143 \\
& PNL & 0,340 & 1 & 66 & 0,562 \\
\multirow{2}{*}{ Akhir } & PMH & 0,002 & 1 & 66 & 0,967 \\
& PNL & 0,882 & 1 & 66 & 0,351 \\
\hline
\end{tabular}

Keterangan:

PMH: Pemahaman Matematis

PNL: Penalaran Matematis

Dari Tabel 7 diperoleh simpulan bahwa baik pada kemampuan awal maupun kemampuan akhir varians masing-masing variabel-variabel terikatnya untuk kelas dengan pendekatan problem solving maupun kelas dengan pendekatan problem posing homogen.

Uji beda rata-rata univariat menggunakan one sample t-test.Analisis ini digunakan untuk menguji pengaruh pendekatan pembelajaran problem solving dan problem posing menggunakan one sample t-test.

Tabel 8. Ringkasan Hasil Analisis Uji Beda Rata-rata Univariat

\begin{tabular}{ccccc}
\hline \multicolumn{2}{c}{ Variabel Terikat } & t & df1 & $\mathbf{t}_{\text {tabel }}$ \\
\hline \multirow{2}{*}{ Kelas $P S$} & PMH & 6,448 & 33 & 1,692 \\
& PNL & 5,222 & 33 & 1,692 \\
\multirow{2}{*}{ Kelas $P P$} & PMH & 2,994 & 33 & 1,692 \\
& PNL & 6,220 & 33 & 1,692 \\
\hline
\end{tabular}

Keterangan:

PS: Pendekatan Problem Solving

PP: Pendekatan Problem Posing

PMH: Pemahaman Matematis

PNL: Penalaran Matematis

Berdasarkan Tabel 8 diperoleh simpulan bahwa pendekatan pembelajaran problem solving efektif ditinjau dari kemampuan pemahaman dan penalaran matematis, dan pendekatan pembelajaran problem posing efektif ditinjau dari kemampuan pemahaman dan penalaran matematis.

Analisis untuk uji beda rata-rata multivariat menggunakan uji $\mathrm{F}$ dengan rumus $T^{2}$ Hotteling. Dari hasil analisisnya, dapat disimpulkan bahwa rata-rata kemampuan awal pemahaman dan penalaran matematis siswa kelas dengan pendekatan problem solving maupun kelas dengan pendekatan problem posing sama.Sedangkan rata-rata kemampuan akhir pemahaman dan penalaran matematis siswa kelas dengan pendekatan problem solving maupun kelas dengan pendekatan problem posing berbeda.

Berdasarkan pengujian hipotesis tersebut, uji t dengan kriteria Bonferroni hanya dilakukan pada kemampuan akhir kelas dengan pendekatan problem solving maupun kelas dengan pendekatan problem posing. Kriteria keputusannya dengan $\alpha=0,05$ adalah $\mathrm{H}_{0}$ ditolak jika $t_{\text {hitung }}>$ $t_{\alpha / 2} ;\left(n_{1}+n_{2}-2\right)$.

Berikut adalah tabel ringkasan hasil analisis uji t dengan kriteria Bonferroni kemampuan akhir kelas dengan pendekatan problem solving maupun kelas dengan pendekatan problem posing disajikan seperti pada Tabel 9. Ratarata kemampuan akhir suatu variabel terikat kelas dengan pendekatan problem solving lebih tinggi dibandingkan kelas dengan pendekatan problem posing $\left(\mathrm{H}_{0}\right.$ ditolak $)$ jika $t_{\text {hitung }}>$ $t_{\text {tabel }}$. 
Tabel 9. Ringkasan Hasil Analisis Uji t dengan kriteria Bonferroni Kemampuan Akhir Kelas dengan pendekatan problem solving maupun kelas dengan pendekatan problem posing

\begin{tabular}{cccc}
\hline Variabel & $\boldsymbol{t}_{\text {hitung }}$ & df & $\boldsymbol{t}_{\text {tabel }}$ \\
\hline PMH & 2,523 & 66 & 1,997 \\
PNL & $-1,325$ & 66 & 1,997 \\
\hline
\end{tabular}

Keterangan:

PMH: Pemahaman Matematis

PNL: Penalaran Matematis

Berdasarkan Tabel 9, diperoleh simpulan bahwa rata-rata kemampuan akhir pemahaman matematis siswa kelas dengan pendekatan problem solving lebih efektif dari kelas dengan pendekatan problem posing tetapi tidak lebih efektif ditinjau dari kemampuan penalaran matematis.

Dalam penelitian ini telah diterapkan pendekatan problem solving dan problem posing pada materi bangun ruang sisi datar kelas VIII SMP Negeri 4 Ngaglik tahun pelajaran 2012/ 2013. Beberapa hal yang diselidiki dalam penelitian ini diantaranya adalah mendeskripsikan keefektifan dari kedua pendekatan dan perbedaan dari pendekatan pembelajaran ditinjaudari masing-masingkemampuanpemahaman maupun penalaran matematis siswa.Berikut ini adalah pembahasan dari masalah yang telah diselidiki.

Berdasarkan Tabel 2 dan 4 diketahui bahwa pada kelas dengan pendekatan problem solving dan problem posing terjadi peningkatan rata-rata skor baik pada kemampuan pemahaman maupun penalaran matematis. Peningkatan tersebut dapat dilihat dari hasil pre-test dan posttest kemampuan pemahaman dan penalaran matematis kelas dengan pendekatan problem solvingdan problem posing. Hal ini juga diperkuat dengan persentase skor tiap aspek berdasarkan Tabel 1 dan 3 yang juga menunjukkan peningkatan baik pada kemampuan pemahaman maupun penalaran matematis. Peningkatan ini menunjukkan bahwa pembelajaran problem solving efektif ditinjau dari kemampuan pemahaman dan penalaran matematis. Hal ini juga diperkuat oleh pengujian hipotesis menggunkan uji univariat one-sample $t$ test pada Tabel 8 menunjukkan bahwa rata-rata skor kemampuan akhir pemahaman dan penalaran matematis siswa lebih tinggi dari standar yang telah ditentukan, dengan kata lain pendekatan pembelajaran problem solvingdan problem posing efektif ditinjau dari kemampuan pemahaman dan penalaran matematis siswa SMP Negeri 4 Ngaglik pada materi bangun ruang sisi datar.
Hasil tersebut juga sejalan dengan NCTM (2000, p.18) dimana disebutkan bahwa pembelajaran matematika yang efektif memerlukan komitmen yang serius dalam pengembangan pemahaman matematika siswa. Guru harus tahu bagaimana mengajukan pertanyaan dan rencana pelajaran yang mengungkapkan pengetahuan siswa sebelumnya, kemudian dapat merancang pengalaman dan pelajaran yang merespon, dan membangun, pengetahuan ini.

Pembelajaran dengan pemahaman dapat lebih meningkatkan interaksi siswa dalam kelas, baik dalam menyampaikan ide, dugaan, evaluasi bahkan dapat mengembangkan kemampuan penalaran matematis mereka. Dengan adanya kemampuan-kemampuan tersebut guru dapat membantu siswa untuk membangun pengetahuannya sendiri dengan lebih baik. Menurut pendapat Jacobsen, Eggen, \& Kauchak (2009, p.249) bahwa problem solving sebagai salah satu pendekatan pengajaran berbasis masalah di mana guru membantu siswa untuk belajar memecahkan masalah melalui pengalaman-pengalaman pembelajaran hands-on. Pada pendekatan pembelajaran problem solving siswa diberikan banyak kesempatan untuk belajar mengembangkan pemahaman dan penalaran matematis siswa. Kesempatan ini dapat dilihat pada saat siswa menyelesaikan masalah yang diberikan, berdiskusi, dan presentasi.

Faktor yang menyebabkanpembelajaran dengan problem posing menunjukkan hasil yang lebih baik dikarenakan mempunyai dua tahapan kegiatan kognitif yang mendukung siswa untuk belajar aktif. Kedua tahapan tersebut adalah accepting (menerima) dan challenging (menantang). Tahap menerima adalah suatu kegiatan siswa menerima situasi-situasi yang diberikan guru atau situasi-situasi yang sudah ditentukan.Sedangkan tahap menantang adalah suatu kegiatan siswa menantang situasi tersebut dalam rangka perumusan soal.

Pembelajaran baik dengan pendekatan problem solving maupun problem posing masing-masing efektif ditinjau dari kemampuan pemahaman dan penalaran matematis siswa. Hasil uji multivariat menunjukkan bahwa terdapat perbedaan keefektifan pendekatan pembelajaran (problem solving dan problem posing) ditinjau dari kemampuan pemahaman dan penalaran matematis. Oleh karena itu, secara rata-rata, kemampuan pemahaman dan penalaran matematis siswa yang belajar dengan pendekatan pembelajaran problem solving dan problem posing tidak dapat dianggap sama. Hasil ini 
sudah diduga sebelumnya, karena secara praktis pembelajaran dengan menggunakan pendekatan problem solving berbeda dengan pembelajaran dengan pendekatan problem posing.Perbedaan kemampuan pemahaman matematis siswa terlihat pada Tabel 9. Berdasarkan Tabel 9 diperoleh simpulan bahwa pendekatan problem solving lebih efektif dari pendekatan problem posing ditinjau dari kemampuan pemahaman matematis tetapi tidak lebih efektif ditinjau dari kemampuan penalaran matematis.

Berdasarkan Tabel 1 dan 3 terlihat peningkatan persentase kemampuan pemahaman dan penalaran matematis pada pre-test dan posttest baik pada kelas dengan pendekatan problem solving maupun kelas dengan pendekatan problem posing. Perbedaan persentase yang paling besar pada kemampuan pemahaman matematis terlihat dalam hasil post-test dalam aspek mengembangkan syarat perlu atau syarat cukup dari suatu konsep. Pada aspek tersebut terdapat selisih persentase hingga $29,9 \%$ dimana kelas dengan pendekatan problem solving lebih unggul. Hasil persentase skor post-test pada tiap aspek kemampuan penalaran matematis, kelas dengan pendekatan problem posing dapat dikatan lebih unggul.

Pada problem solving, setelah memahami konsep pada materi terkait, siswa diberikan contoh soal rutin dan soal yang tidak rutin. Soal rutin berisi penerapan konsep yang telah dikuasai, sedangkan soal tidak rutin berisi penerapan konsep yang telah dikuasi dan konsep-konsep selain konsep pada materi yang sedang dibahas. Dengan demikian siswa memperoleh kesempatan yang lebih banyak dalam menghadapi berbagai masalah matematika, sehingga siswa terbiasa untuk menggunakan pemahaman yang telah mereka miliki untuk mengembangkan pemahaman yang baru mereka peroleh. Hal ini sejalan dengan pendapat Sanjaya (2007, p.220) bahwa salah satu keunggulan pembelajaran dengan pendekatan problem solving adalah membantu siswa untuk mengembangkan pemahaman barunya dalam pembelajaran yang mereka ikuti. Sedangkan pada pendekatan problem posing, terdapat salah satu langkah yaitu siswa menyusun sendiri pertanyaan/masalah berdasarkan situasi yang telah tersedia. Berdasarkan hasil LKS pendekatan problem posing, pertanyaan-pertanyaan yang dibuat oleh siswa cenderung berupa pertanyaan konseptual, artinya hanya membutuhkan konsep yang terkait dengan materi yang sedang dipelajari. Menurut Posamentier, Smith, \& Stepelman (2010, p.
107), masalah matematika merupakan tantangan jika penyelesaiannya diperlukan kreativitas, wawasan yang mendalam, berpikir kritis, atau imajinasi. Hal ini berarti pertanyaan-pertanyaan yang dibuat oleh siswa dalam kelas problem posing bukan merupakan masalah matematika. Kondisi ini mengakibatkan kesempatan menggali kemampuan pemahaman matematis siswa kurang.

Pada pembelajaran dengan pendekatan problem posing, siswa dihadapkan dengan situasi tertentu dan diperintahkan untuk menyusun pertanyaan yang terkait dengan tujuan pembelajaran berdasarkan situasi yang telah tersedia. Pada saat itu siswa memperoleh kesempatan untuk menggali informasi seluas-luasnya yang terdapat pada situasi dan menyatakan situasi dalam simbol, gambar, kata-kata dan persamaan matematis yang kemudian disusun dalam bentuk pertanyaan matematika. Hal ini dikemukakan pada salah satu tahapan utama problem posing yang dikemukakan Brown \& Walter (2005) yaitu mendaftar apa yang diketahui dari masalah atau situasi yang diberikan. Dengan mendaftar apa yang diketahui berarti siswa berusaha menyatakan kembali masalah atau situasi yang ada dalam ide dan bentuk yang lain. Dalam NCTM juga disebutkan bahwa gagasan-gagasan atau ide-ide matematika yang ditampilkan siswa dalam upayanya mencari suatu solusi dari masalah yang sedang dihadapi merupakan bentuk penalaran yang dimunculkan oleh siswa. Pada pendekatan problem solving, siswa juga menyatakan masalah yang diberikan dalam LKS (Lembar Kegiatan Siswa) ke dalam bentuk gambar, simbol, kata-kata ataupun persamaan matematis. Dengan demikian baik pendekatan problem solving maupun problem posing memberikan kesempatan yang lebih luas kepada siswa untuk memperdalam kemampuan penalaran matematis.

\section{SIMPULAN}

Berdasarkan hasil analisis data dan pembahasan, maka dapat disimpulkan bahwa: pendekatan problem solving efektif ditinjau dari kemampuan pemahaman dan penalaran matematis; pendekatan problem posing efektif ditinjau dari kemampuan pemahaman dan penalaran matematis siswa; dan pendekatan problem solving lebih efektif daripada pendekatan problem posing ditinjau dari kemampuan pemahaman matematis tetapi pendekatan problem solving tidak lebih efektif daripada pendekatan problem posing ditinjau dari kemampuan penalaran 
matematis siswa SMP Negeri 4 Ngaglik pada materi bangun ruang sisi datar.

\section{DAFTAR PUSTAKA}

Barmby, P., Harries, T., Higgins, S., \& Suggate, J. (2007). How can we asses mathematical understanding? Procedings of the 31" Conference of the International Group for the Psychology of Mathematics Education, 2, 41-48. Seoul: PME.

Brown, S.I., \& Walter, M.L. (2005). The art of problem posing. Mahwah, NJ: Lawrence Erlbaum Associates Publishers.

Dahlan, J.A. (2004). Meningkatkan kemampuan penalaran dan pemahaman matematika siswa sekolah lanjutan tingkat pertama melalui pendekatan pembelajaran openended. Disertasi. Bandung: Sekolah Pascasarjana, Universitas Pendidikan Indonesia.

De Lange, J., \& Romberg, T.A. (2004). Monitoring student progress. Dalam T.A.Romberg (Eds.), Standard based mathematics assessment in middle school: Rethingking classroom practice (pp.5-21). New York, NY: Teacher College Press.

Depdiknas. (2006). Peraturan menteri pendidikan nasional $R l$ nomor 22 tahun 2006, tentang standar lsi untuk satuan pendidikan dasar dan menengah.

Depdiknas. (2007a). Peraturan menteri pendidikan nasional $\mathrm{Rl}$ nomor 41 tahun 2007, tentang standar proses untuk satuan pendidikan dasar dan menengah.

Depdiknas. (2007b). Laporan ujian nasional tahun pelajaran 2006/2007.

Depdiknas. (2008). Laporan ujian nasional tahun pelajaran 2007/2008.

Depdiknas. (2009). Laporan ujian nasional tahun pelajaran 2008/2009.

Depdiknas. (2010). Laporan ujian nasional tahun pelajaran 2009/2010.

Depdiknas. (2011). Laporan ujian nasional tahun pelajaran 2010/2011.

Driver, R. \& Leach, J. (1993). A constructivist view of learning: Children's and nature of science. Journal NSTA: What Research Says to the Science Teacher-The Science, Technology, Society Movement, 3(1), 103112.
English, L.D. (2009). Mathematical reasoning: Analogies, metaphors, and images. Madison Avenue, NY: Routledge.

Suherman, E., Turmudi., Suryadi, D., Herman, T., Suhendra, Prabawanto, S., Nurjanah, \& Rohayati, A. (2003). Strategi pembelajaran matematika kontemporer (Rev.ed.). Bandung: JICA.

Glass, G.V., \& Hopkins, K.D. (1984). Statistical methods in education and psycology $\left(2^{\text {nd }} e d\right)$. Englewood, NJ: Prentice Hall, Inc.

Haylock, D., \& Cockbum, A. (2008). Understanding mathematics for young children: A guide for fondation stage and lowerprimary teacher. London, UK: SAGE Publication Inc.

Haylock, D., \& Thangata, F. (2007). Key concepts in teaching primary mathematics. Thousand Oaks, CA: SAGE Publication.

Jacobsen, D.A., Eggen P., \& Kauchak, D. (2009). Metode-metode pengajaran meningkatkan belajar siswa TK-SMA (edisi ke-8). (Terjemahan Achmad Fawaid \& Khoirul Anam). Upper Saddle River, NJ: Pearson Education. (Buku asli diterbitkan tahun 2009).

Johnson, R.A., \& Wichern, D.W. (2007). Applied multivariate statistical analysis. Upper Saddle River, NJ: Pearson Education.

Keraf, G. (1982). Argumen dan narasi. komposisi lanjutan III. Jakarta: Gramedia

Lavy, I., \& Shriki, A. (2007). Problem posing as a model means for developing mathematical knowledge of prospective teachers. Proceeding of the $31^{\text {st }}$ Conference of the Intemational Group for the Psychology of Mathematics Education, Seoul, 3, 129-136.

Lithner, 1. (2012). Learning mathematics by creative or imitative reasoning. Journal $12^{\text {st }} \quad$ International Congress on Mathematical Education. Seoul, Korea.

Martin, W.G., \& Kasmer, L. (2009). Focus in high school mathematics: Reasoning and sense making. Teaching Children Mathematics, 284-291.

Mullis, I.V.S., Martin, M.O., Foy, P., Olson, J.F., Preuschoff, C., Erberber, E., Arora, A., \& Galia, J. (2008). TIMSS 2007 
international mathematics report: finding from lEA's trends in international mathematics and science study at the fourth and eight grades. Chestnut Hill, MA: TIMSS \& PIRLS Intemational Study Center.

Melianingsih, N., \& Sugiman, S. (2015). Keefektifan pendekatan open-ended dan problem solving pada pembelajaran bangun ruang sisi datar di SMP. Jurnal Riset Pendidikan Matematika, 2(2), 211 223.

doi:http://dx.doi.org/10.21831/jrpm.v2i2. 7335

Michener, E.R. (1978). Understanding understanding mathematics. Cognitive Science, 2(4), 361-383.

NCTM. (2000). Principles and standarts for school mathematics. Reston, VA: The National Council of Teachers of Mathematics, Inc.

Nugraha, T., \& Mahmudi, A. (2015). Keefektifan pembelajaran berbasis masalah dan problem posing ditinjau dari kemampuan berpikir logis dan kritis. Jurnal Riset Pendidikan Matematika, 2(1), $107 \quad$ - 120. doi:http://dx.doi.org/10.21831/jrpm.v2i1. 7154

OECD. (2010). PISA 2009 results: What students know and can do student performance in reading, mathematics and science (volume 1). Corrigenda.

Orlich, D.C, Harder, R.J., Callahan, R.C., Trevisan, M.S., Brown, A.H., \&Miller, D.E. (2012). Teaching strategies: a guide to effective instruction $\left(10^{\text {th }} \mathrm{ed}\right)$. Belmount, CA: Wadsworth Cengage Learning.

O'Shea, J. (2010). Teaching mathematical problem solving in the primary school. Resource \& Research Guides, 2(5).
Limerick: National centre for excellence in mathematics and science and learning.

Posamentier, A.S., Smith, B.S., \& Stepelman, J. (2010). Teaching secondary mathematics techniques and enrichment units ( $8^{\text {th }}$ ed.). Boston, MA: PearsonEducation, Inc.

Sanjaya, W. (2007). Strategi pembelajaran berorientasi standar proses pendidikan. Jakarta: Kencana.

Setyaningsih, E., \& Widjajanti, D. (2015). Keefektifan pendekatan problem posing ditinjau dari prestasi belajar, kemampuan koneksi matematis, dan disposisi matematis. PYTHAGORAS: Jurnal Pendidikan Matematika, 10(1), 28-37. doi:http://dx.doi.org/10.21831/pg.v10i1.9 100

Shanti, W., \& Abadi, A. (2015). Keefektifan pendekatan problem solving dan problem posing dengan setting kooperatif dalam pembelajaran matematika. Jurnal Riset Pendidikan Matematika, 2(1), 121 - 134. doi:http://dx.doi.org/10.21831/jrpm.v2i1 . 7155

Silver, E. A., \& Cai, J. (1996). An analysis of arithmetic problem posing by middleschool students. Journal for Research in Mathematics Education, 27(5), 521-539.

Silver, E. A., Downs, J. M., Leung, S. S., et al. (1996). Posing mathematical problems: an exploratory study.Journal for Research in Mathematics Education, 27(3),293-309.

Stevens, J. (2002). Applied multivariate statistics for the social sciences $\left(4^{\text {th }} e d\right.$.). Mahwah, NJ: Lawrence Erlbaum Associates, Inc.

Xia, X., Lu, C., \& Wang, B.B. (2008). Research on mathematics instruction experiment based problem posing. Journal of mathematics education, 1(1), 153-163. 